\title{
Synthesis of new substituted 7,12-dihydro-6,12- methanodibenzo[c,f]azocine-5-carboxylic acids containing a tetracyclic tetrahydroisoquinoline core structure
}

\author{
Agnieszka Grajewska*, Maria Chrzanowska and Wiktoria Adamska
}

Open Access

\author{
Full Research Paper \\ Address: \\ Faculty of Chemistry, Adam Mickiewicz University, ul. Uniwersytetu \\ Poznańskiego 8, 61-614 Poznań, Poland \\ Email: \\ Agnieszka Grajewska* - agako@amu.edu.pl \\ * Corresponding author \\ Keywords: \\ amino acids; cyclization; multicomponent reactions; synthetic \\ methods; tetrahydroisoquinoline
}

Beilstein J. Org. Chem. 2021, 17, 2511-2519.

https://doi.org/10.3762/bjoc.17.168

Received: 15 June 2021

Accepted: 27 September 2021

Published: 07 October 2021

Associate Editor: C. Stephenson

(C) 2021 Grajewska et al.; licensee Beilstein-Institut.

License and terms: see end of document.

\begin{abstract}
A convenient and simple protocol has been developed for the synthesis of a series of new tetracyclic tetrahydroisoquinoline derivatives, 7,12-dihydro-6,12-methanodibenzo[c,f]-azocine-5-carboxylic acids by three component Petasis reaction with the use of aminoacetaldehyde acetals bearing substituted benzyl groups as the amine components followed by Pomeranz-Fritsch double cyclization reaction. By applying this method, several acids have been prepared in satisfactory yields. An unprecedented chemical behavior of a Petasis reaction product in diluted $\mathrm{HCl}$ solution leading to the formation of a phenylglycine derivative has been observed and the mechanism explaining such reactivity has been proposed.
\end{abstract}

\section{Introduction}

The tetrahydroisoquinoline moiety is the key structure in large number of natural and synthetic biologically important molecules. Among them, isoquinoline alkaloids constitute a large family of natural products exhibiting a huge range of structural diversity and biological activity [1-3]. Within this family several structural motifs can be identified, for instance, the isopavines, constrained alkaloids possessing the 1,2,3,4-tetrahydroisoquinoline skeleton incorporated into the double cyclized azabicyclo[3.2.2]nonane, isolated from Papaveraceae and Ranunculaceae species. Natural isopavines (e.g., amurensi- nine (I), and $O$-methylthalisopavine (II), Figure 1) as well as their synthetic analogues have attracted much attention [4,5] because of their interactions with the receptors in the central nervous system promising for the treatment of nervous system disorders, such as Parkinson's and Alzheimer's disease [6,7].

Hanessian and co-workers designed isopavines of type III (Figure 1) that act as morphinomimethics and bind strongly to human opioid receptors [8,9]. The synthesis of these compounds involved the stereocontrolled [1,2]-Stevens 


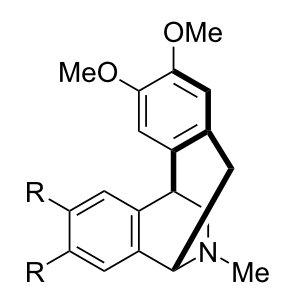

$$
\begin{aligned}
& \text { I } \mathrm{R}+\mathrm{R}=\mathrm{OCH}_{2} \mathrm{O} \\
& \text { (-)-amurensinine } \\
& \text { II } \mathrm{R}=\mathrm{OMe} \\
& \text { (-)-O-methylthalisopavine }
\end{aligned}
$$

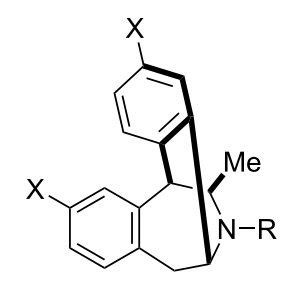

III $\mathrm{X}=\mathrm{H}, \mathrm{OH}, \mathrm{OMe}, \mathrm{NHBn}$ $\mathrm{R}=\mathrm{Me}, \mathrm{CPM}$
Figure 1: Natural isopavine alkaloids and synthetic derivatives of isopavine.

rearrangement of dihydromethanodibenzoazocines. Dihydromethanodibenzoazocines are example of strained, methylene-bridged tetrahydroisoquinolines (Figure 2) that have attracted much interest of scientists not only due to their resemblance to isopavines and thus their medicinal significance in the central nervous system but also as a building blocks for the synthesis of alkaloids $[10,11]$.

The classical strategy for the synthesis of dihydromethanodibenzoazocines is based on the use of $N, N$-dibenzylaminoacetaldehydes [8,9] and less often $\alpha$-dibenzylaminoketone $[12,13]$ derivatives in the intramolecular Friedel-Crafts double cyclization reaction and $N, N$-dibenzylaminoacetaldehyde dialkyl acetals [12,14-16] in the Pomeranz-Fritsch-type double cyclization reaction. There is also one example of employing $p$-quinol acetates as substrates for the synthesis of these<smiles>c1ccc2c(c1)CN1C[C@H]2Cc2ccccc21</smiles>

Figure 2: The structure and numbering of dihydromethanodibenzoazocine.

compounds [17]. Recently, a methodology for the synthesis of dihydromethanodibenzoazocines based on a combination of Friedel-Crafts and Pictet-Spengler reactions was proposed by Moshkin et al. [18].

We have developed a convenient method for the preparation of C-1-substituted tetrahydroisoquinoline derivatives by using the Petasis three-component reaction followed by the Pomeranz-Fritsch-Bobbitt cyclization. The Petasis reaction between boronic acids, carbonyl derivatives, and amines, leading to the formation of amino acids and the Pomeranz-Fritsch-Bobbitt cyclization of amino acetals, leading to the construction of $\mathrm{C}$-1-functionalized tetrahydroisoquinoline rings, are presented in Scheme 1.

In the Petasis reaction we applied aminoacetaldehyde acetals as the amine component which enabled the preparation of the substrates for the Pomeranz-Fritsch-Bobbitt cyclization in one simple step. The Petasis reaction products were further transformed into racemic tetrahydroisoquinoline-1-carboxylic acids [19], simple isoquinoline alkaloids [20], and (+)-6,7-dimethoxy1,2,3,4-tetrahydroisoquinoline-1-carboxylic acid [21].

the Petasis synthesis of amino acids:

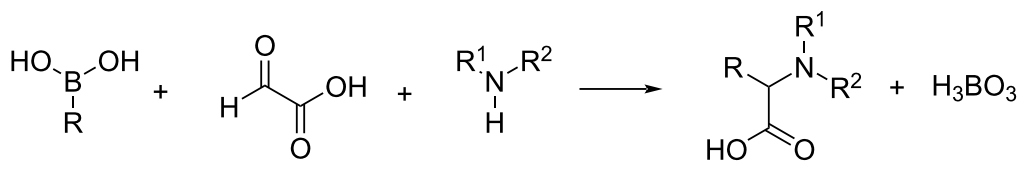

the Pomeranz-Fritsch-Bobbitt synthesis of tetrahydroisoquinoline derivatives:

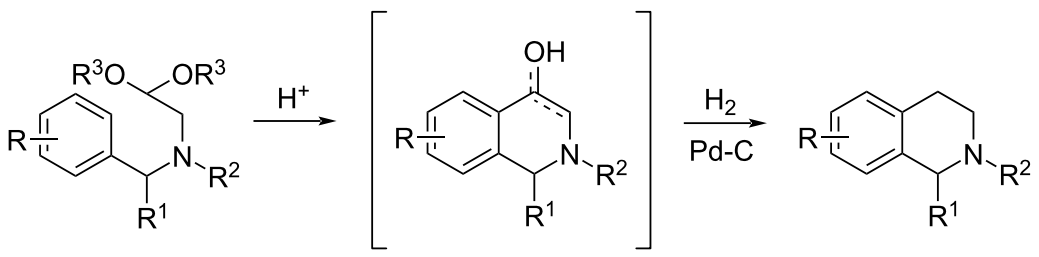


In this paper we report a straightforward synthesis of new strained tetracyclic tetrahydroisoquinoline derivatives, variously substituted 7,12-dihydro-6,12methanodibenzo[ $[c, f]$ azocine-5-carboxylic acids, via our modified method based on a combination of the Petasis reaction, in which we used aminoacetaldehyde acetals with substituted $N$-benzyl groups as the amine component and the Pomeranz-Fritsch double cyclization reaction (Scheme 2).

\section{Results and Discussion}

Our investigations commenced with the synthesis of $N$-benzylated aminoacetaldehyde acetals $\mathbf{3 a}-\mathbf{e}$, the amine components for the Petasis reaction. The condensation of aminoacetaldehyde diethyl acetal $\mathbf{1}$ and 2,3-dimethoxybenzaldehyde (2a) was carried out at $\mathrm{rt}$ in anhydrous ethanol and the formed imine was then reduced in situ with sodium borohydride to give the prod- uct 3a with $98 \%$ yield. The synthesis of further $N$-benzylated aminoacetaldehyde acetals $\mathbf{3 b}-\mathbf{e}$ was performed in these reaction conditions in $\mathrm{EtOH}$ or $\mathrm{MeOH}$ to provide the desired products with high overall yields of $85-99 \%$ as indicated in Scheme 3. The aminoacetals 3a-e were suitable for use directly in the next step of the synthesis without further purification.

Then, the $N$-benzylated aminoacetals $3 \mathbf{a}-\mathbf{e}$ were subjected to the Petasis reaction with glyoxylic acid hydrate (4) and the appropriate boronic acids 5a-d carried out in DCM at $\mathrm{rt}$ for $24 \mathrm{~h}$ to afford amino acids $\mathbf{6 a}-\mathbf{g}$ (Scheme 4).

The condensation of $N$-(2,3-dimethoxybenzyl)aminoacetaldehyde acetal (3a) with glyoxylic acid hydrate (4) and 3,4dimethoxyphenylboronic acid (5a) afforded the Petasis reaction product $6 \mathbf{a}$ in a high $94 \%$ yield.<smiles>[R][R]1ccc2c(c1)C1c3cc[R](C(=O)O)cc3CN1C2</smiles>

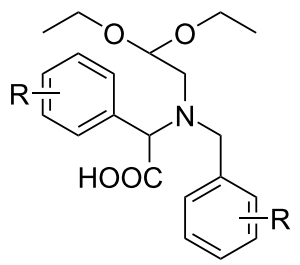<smiles>C=C</smiles><smiles>[R]OCC(CNCc1ccc[R]([R])c1)OCC</smiles>

Scheme 2: The synthesis of 7,12-dihydro-6,12-methanodibenzo[c,f]azocine-5-carboxylic acids via a combination of the Petasis reaction and the Pomeranz-Fritsch reaction - a retrosynthetic approach.

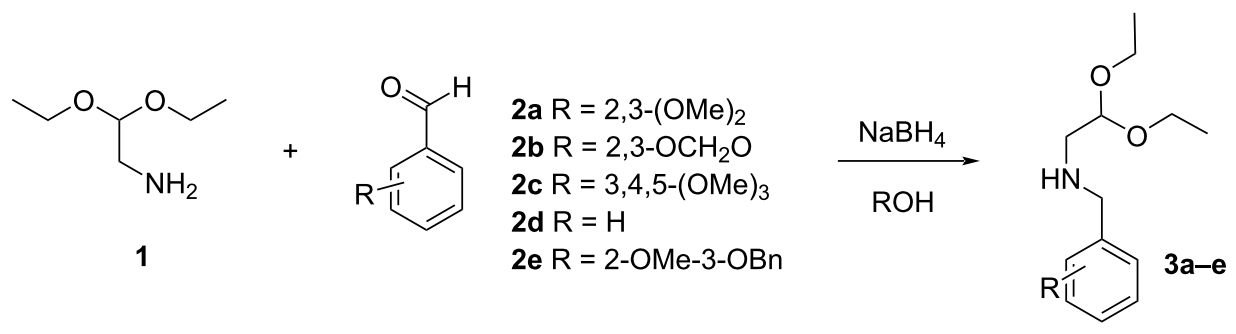<smiles>CCOC(CNCc1cccc(OC)c1OC)OCC</smiles><smiles>CCOC(CNCc1cccc2c1OCO2)OCC</smiles>

$3 a, 98 \%^{a}$<smiles>CCOC(CNCc1cc(OC)c(OC)c(OC)c1)OCC</smiles>

3c, $97 \%^{\mathrm{b}}$<smiles>CCOC(CNCc1ccccc1)OCC</smiles>

$3 d, 85 \%^{a}$<smiles>CCOC(CNCc1cccc(OCc2ccccc2)c1OC)OCC</smiles>

$3 \mathbf{e}, 99 \%$ b 


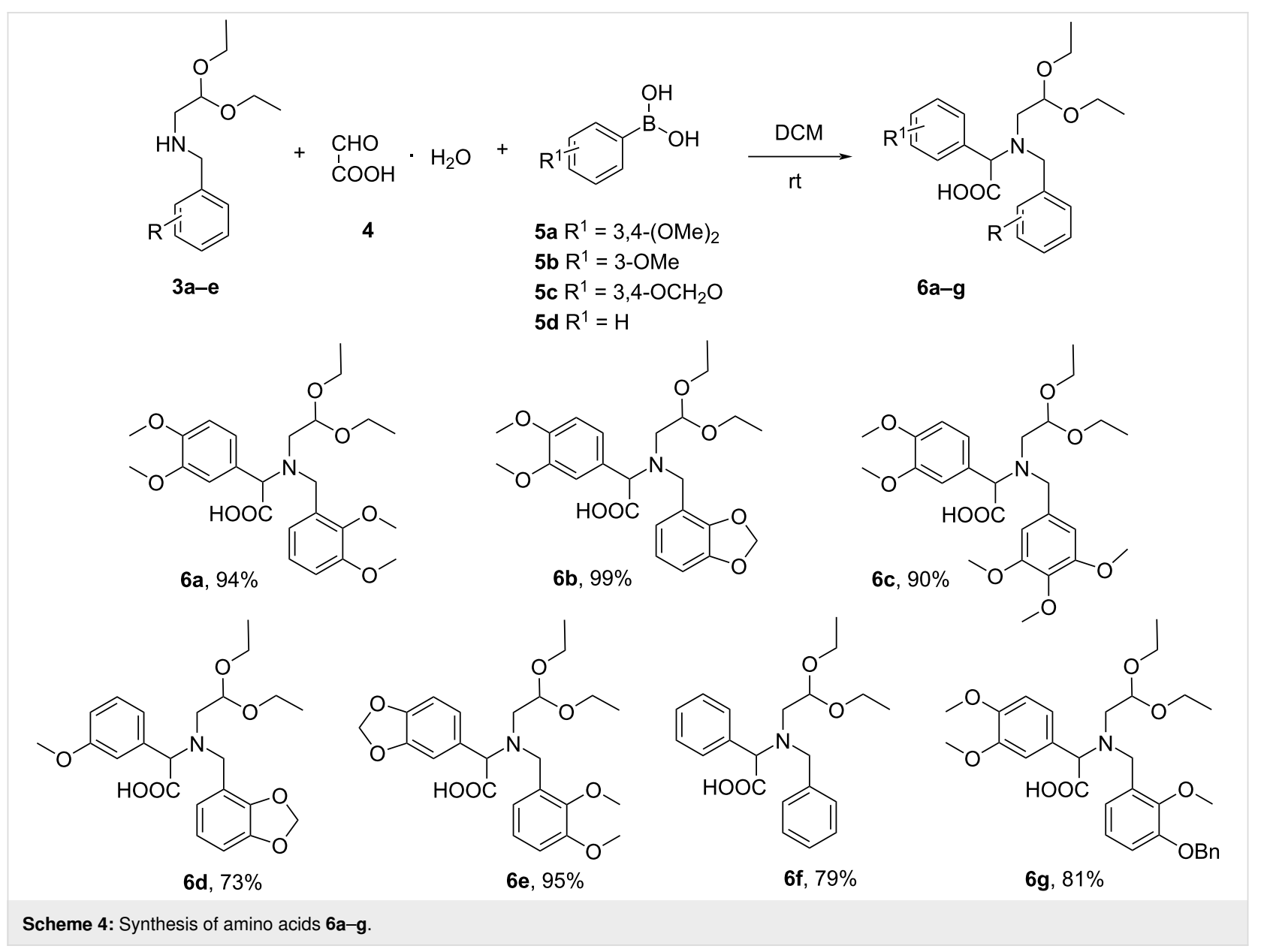

The double cyclization reaction was easily performed by treatment of $6 \mathrm{a}$ with $20 \% \mathrm{HCl}$ for $24 \mathrm{~h}$ to give dihydromethanodibenzoazocine-5-carboxylic acid (7a, Scheme 5) in $72 \%$ yield by extraction of the neutralized reaction mixture. Compound 7a was obtained in two simple steps from 3a with an overall yield of $67 \%$.

Then the amino acid 6a was subjected to cyclization under different acidic conditions (not shown). The reaction of $\mathbf{6 a}$ with $\mathrm{TiCl}_{4}$ or $\mathrm{SnCl}_{4}$ in DCM at $0{ }^{\circ} \mathrm{C}$ led exclusively to the formation of 7a (TLC analysis) but it was impossible to isolate the product in a pure form probably due to the formation of the salts.

When 6a was treated with $70 \% \mathrm{HClO}_{4}$ for 2 hours, the TLC analysis indicated the presence of $\mathbf{7 a}$ as the main product together with unreacted substrate and other difficult to separate by-products. When the reaction time was prolonged to $24 \mathrm{~h}$ all the substrate was consumed but a mixture of unidentified products was formed.

Then, $N$-2,3-methylenedioxybenzylamino acid $\mathbf{6 b}$ and $N-3,4,5-$ trimethoxybenzylamino acid $\mathbf{6 c}$ were prepared from boronic acid 5a, glyoxylic acid hydrate (4) and aminoacetals $\mathbf{3 b}$ and $\mathbf{3 c}$, in $99 \%$ and $90 \%$ yield, respectively (Scheme 4). Under the Pomeranz-Fritsch conditions compounds $\mathbf{6 b}$ and $\mathbf{6 c}$ were transformed into dihydromethanodibenzoazocine-5-carboxylic acids $7 \mathbf{b}$ with a yield of $58 \%$ and $7 \mathbf{c}$ with a yield of $69 \%$. The overall yields for compounds $\mathbf{7 b}$ and $\mathbf{7 c}$ starting from $\mathbf{3 b}$ and $\mathbf{3 c}$, were $57 \%$ and $62 \%$, respectively (Scheme 5).

Next, 3-methoxyphenylboronic acid (5b) and 3,4-methylenedioxyphenylboronic acid (5c) reacted easily with aminoacetals 3b and 3a, respectively and glyoxylic acid hydrate (4), affording the corresponding arylglycine derivatives $\mathbf{6 d}$ and $\mathbf{6 e}$, in satisfactory yields of $73 \%$ and $95 \%$, respectively (Scheme 4). After cyclization in $20 \% \mathrm{HCl}$, compounds $6 \mathbf{d}$ and 6 e were transformed into the desired dihydromethanodibenzoazocine-5carboxylic acids $7 \mathbf{d}$ and $7 \mathbf{e}$ with yields of $52 \%$ and $96 \%$, respectively. The overall yields of 7d and 7e (from 3d and 3e, respectively) were $37 \%$ and $91 \%$, respectively (Scheme 5).

In the case of the amino acid $\mathbf{6 f}$, containing insufficiently activated phenyl rings without alkoxy substituents, prepared from phenylboronic acid (5d), glyoxylic acid hydrate (4) and an 
<smiles>[R]c1ccccc1CN1Cc2ccccc2C2c3ccc(C)cc3C(C(=O)O)C21</smiles><smiles>COc1cc2c(cc1OC)C1c3ccc(OC)c(OC)c3CN1CC2C(=O)O</smiles>

$7 a, 72 \%^{a}$<smiles>COc1ccc2c(c1)C1CN3Cc4c(ccc5c4OCO5)C2CN1C3</smiles>

$7 d, 52 \%^{a}$<smiles>COc1cc2c(cc1OC)C1CN(CCc3c1ccc1c3OCO1)C2</smiles>

$7 b, 58 \%^{a}$<smiles>COc1ccc2c(c1OC)CN1CC2Cc2cc3c(cc2C1C(=O)O)OCO3</smiles>

$7 e, 96 \%^{a}$<smiles>COc1cc2c(cc1OC)C(C(=O)O)N1CCc3cc(OC)c(OC)c(OC)c3CC21</smiles>

$7 c, 69 \%^{a}$<smiles>O=C(O)C1c2ccccc2C2CN1Cc1ccccc12</smiles>

$7 f, 67 \%^{b}$

Scheme 5: Synthesis of dihydromethanodibenzoazocine-5-carboxylic acids 7a-f. Conditions: a) $20 \% \mathrm{HCl}, \mathrm{rt}, 24 \mathrm{~h}$; b) 70\% $\mathrm{HClO}_{4}, \mathrm{rt}, 12 \mathrm{~h}$.

$N$-benzyl aminoacetal 3d with good yield 79\% (Scheme 4), it was necessary to perform the cyclization reaction using $70 \%$ $\mathrm{HClO}_{4}$ instead of $20 \% \mathrm{HCl}$. In these conditions, the desired product $7 f$ was obtained with $67 \%$ yield $(53 \%$ overall yield from 3d), while the reaction carried out in $20 \% \mathrm{HCl}$ led to a mixture of products, among which 7f was not detected (Scheme 5).

It should be also mentioned that the amino acid $\mathbf{6 g}$ with a benzyloxy-substituted aromatic ring, obtained in the Petasis reaction of boronic acid 5a, glyoxylic acid hydrate (4), and $O$-benzylvanilin-derived aminoacetal 3e (Scheme 4), when treated with $20 \% \mathrm{HCl}$ or $70 \% \mathrm{HClO}_{4}$ gave a colored complex mixture of decomposition products, probably due to the hydrolysis of the benzyl ether.

Iwakuma et al. [15] reported the synthesis of 1,2,3,4-tetrahydroisoquinoline derivative TA-073 using substituted $N$-acyl aminoacetal as the key intermediate which, depending on the reaction conditions, could be transformed either into TA-073 or the appropriate double cyclized product, isopavine or pavine (not shown) (Scheme 6).

Inspired by these results, we next investigated the possibility of obtaining monocyclized derivatives from the Petasis reaction products of type 6 . In this experiment the amino acid $\mathbf{6 a}$ has been chosen as a model compound and it was treated with $4 \%$ aqueous $\mathrm{HCl}$ in THF at reflux [15]. Surprisingly, in these conditions we isolated the $N$-benzylated phenylglycine derivative $\mathbf{8}$ as the sole product with $87 \%$ yield (Scheme 7 ). When we decreased the concentration of $\mathrm{HCl}$ to $2 \%$ in the reaction with $\mathbf{6 a}$, the substrate was isolated unchanged even after prolonged reaction time.

In light of these results, we investigated the chemical behavior of compound 12, the decarboxylated analogue of $\mathbf{6 a}$, under the reaction conditions that led to products $7 \mathbf{a}$ or $\mathbf{8}$ starting from acid 6a. The substrate for the synthesis of compound $\mathbf{1 2}$ was aminoacetal 3f, obtained with moderate $49 \%$ yield through the condensation of aminoacetaldehyde diethyl acetal (1) and 3,4- 


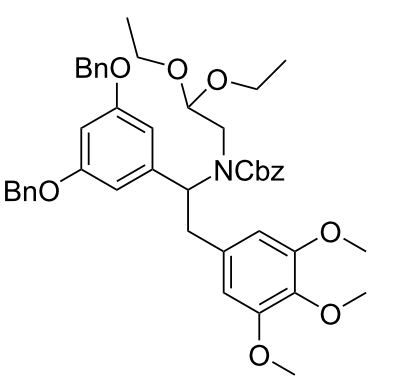

1. $1 \mathrm{~N} \mathrm{HCl}$, THF 2. $\mathrm{Pd}-\mathrm{C} / \mathrm{H}_{2}$<smiles>COc1cc(CC2NCCc3c(O)cc(O)cc32)cc(OC)c1OC</smiles>

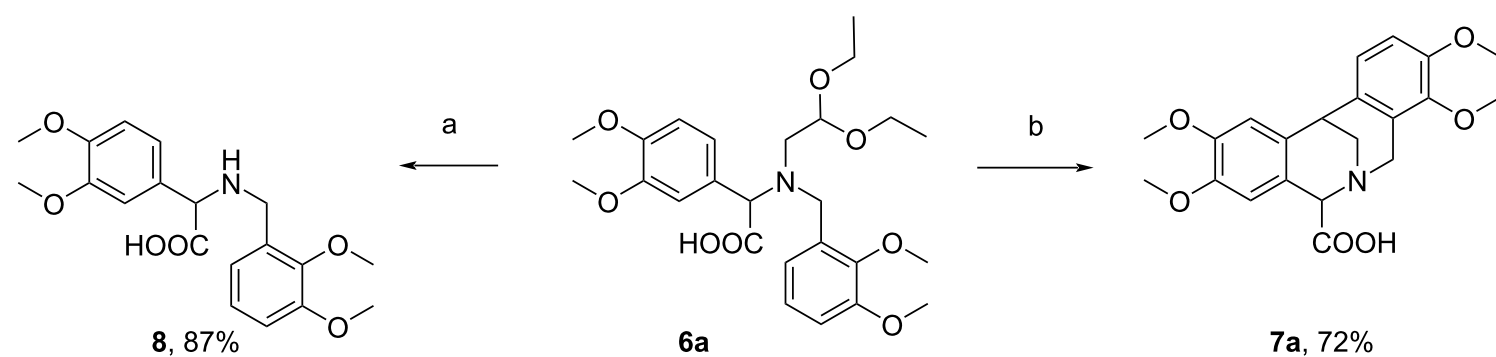

Scheme 7: Reaction of 6 a with $4 \%$ aqueous $\mathrm{HCl}$ solution in $\mathrm{THF}$ and with $20 \%$ aqueous $\mathrm{HCl}$ solution. Conditions: a) $4 \% \mathrm{HCl}$ (aq), THF, reflux; b) $20 \%$ $\mathrm{HCl}$, rt.

dimethoxybenzaldehyde (2f) carried out in refluxing toluene using a Dean-Stark apparatus followed by the reduction with $\mathrm{NaBH}_{4}$ (not shown). When the condensation of acetal 1 and aldehyde $\mathbf{2 f}$ and the subsequent reduction were carried out in $\mathrm{EtOH}$ at $\mathrm{rt}$, according to our procedure applied for the synthesis of aminoacetals $\mathbf{3 a}-\mathbf{e}$, the product $\mathbf{3 f}$ was isolated with $65 \%$ yield (Scheme 8).
In the reaction of aminoacetal $\mathbf{3 f}$ with 2,3-dimethoxybenzyl bromide (13) product 12 was formed, however, it was not pure enough to be used directly in the next step of the synthesis. Purification of the crude reaction mixture by column chromatography was difficult and resulted in a moderate yield of 12 (41\%) due to insufficient differences in the $R_{\mathrm{f}}$ values of compound $\mathbf{1 2}$ and the by-product 2,3-dimethoxybenzyl

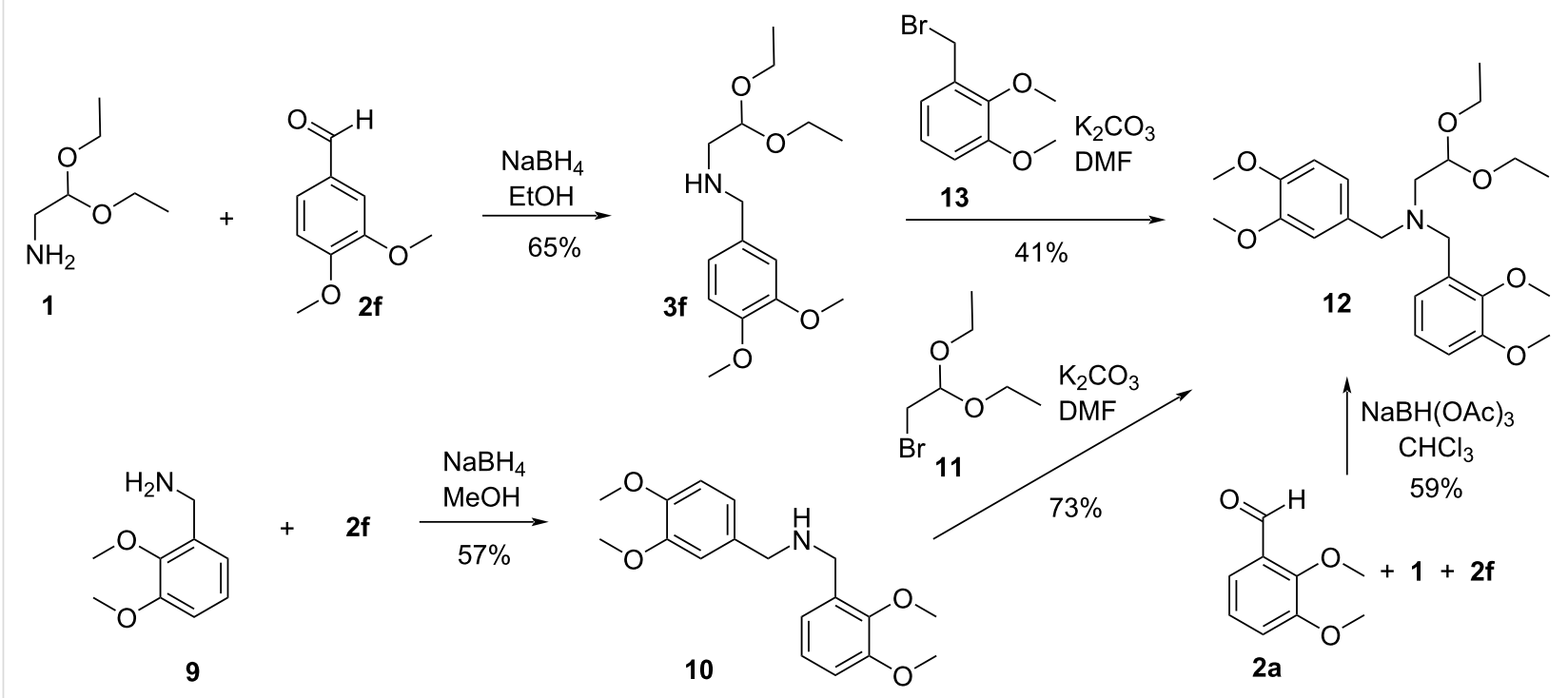


alcohol (not shown), formed through the hydrolysis of $\mathbf{1 3}$ (Scheme 8).

In this situation $N$-(2,3-dimethoxybenzyl)veratrylamine $\mathbf{1 0}$ was chosen as the substrate for the synthesis of the decarboxylated derivative $\mathbf{1 2}$ and simultaneously $\mathbf{1 0}$ was the expected product of its reaction with $4 \% \mathrm{HCl}$. The amine 10 was obtained by reductive amination of veratral (2f) with 2,3-dimethoxybenzylamine (9) with 57\% yield and subsequently alkylated with bromoacetaldehyde diethyl acetal (11) to give 12 with $73 \%$ yield.

Additionally, the aminoacetal $\mathbf{1 2}$ was also synthesized via another route involving a double reductive amination of the aldehydes $2 \mathbf{a}$ and $\mathbf{2 f}$ with aminoacetaldehyde acetal (1) with $59 \%$ yield.

The aminoacetal 12 was then treated with $4 \% \mathrm{HCl}$ in THF at reflux but in contrast to the chemical behavior of amino acid $\mathbf{6 a}$ in the same conditions (see Scheme 7), no reaction was observed. The cyclization reaction of $\mathbf{1 2}$ carried out in $20 \% \mathrm{HCl}$ led, as expected, to the double-cyclized derivative $\mathbf{1 4}$ (Scheme 9).

To explain the difference in the reactivity between $\mathbf{6 a}$ and $\mathbf{1 2}$ we proposed a plausible mechanism for the reaction of $\mathbf{6 a}$ with diluted $\mathrm{HCl}$ (Scheme 10). The mechanism consists of four major steps: the first step is an acid-catalyzed hydrolysis of the<smiles>COc1cc2c(cc1OC)[C@@H]1CN(C2)Cc2c1ccc(OC)c2OC</smiles>

Scheme 9: The chemical behavior of 12 in $4 \%$ aqueous $\mathrm{HCl}$ solution in $\mathrm{THF}$ and in $20 \%$ aqueous $\mathrm{HCl}$ solution.

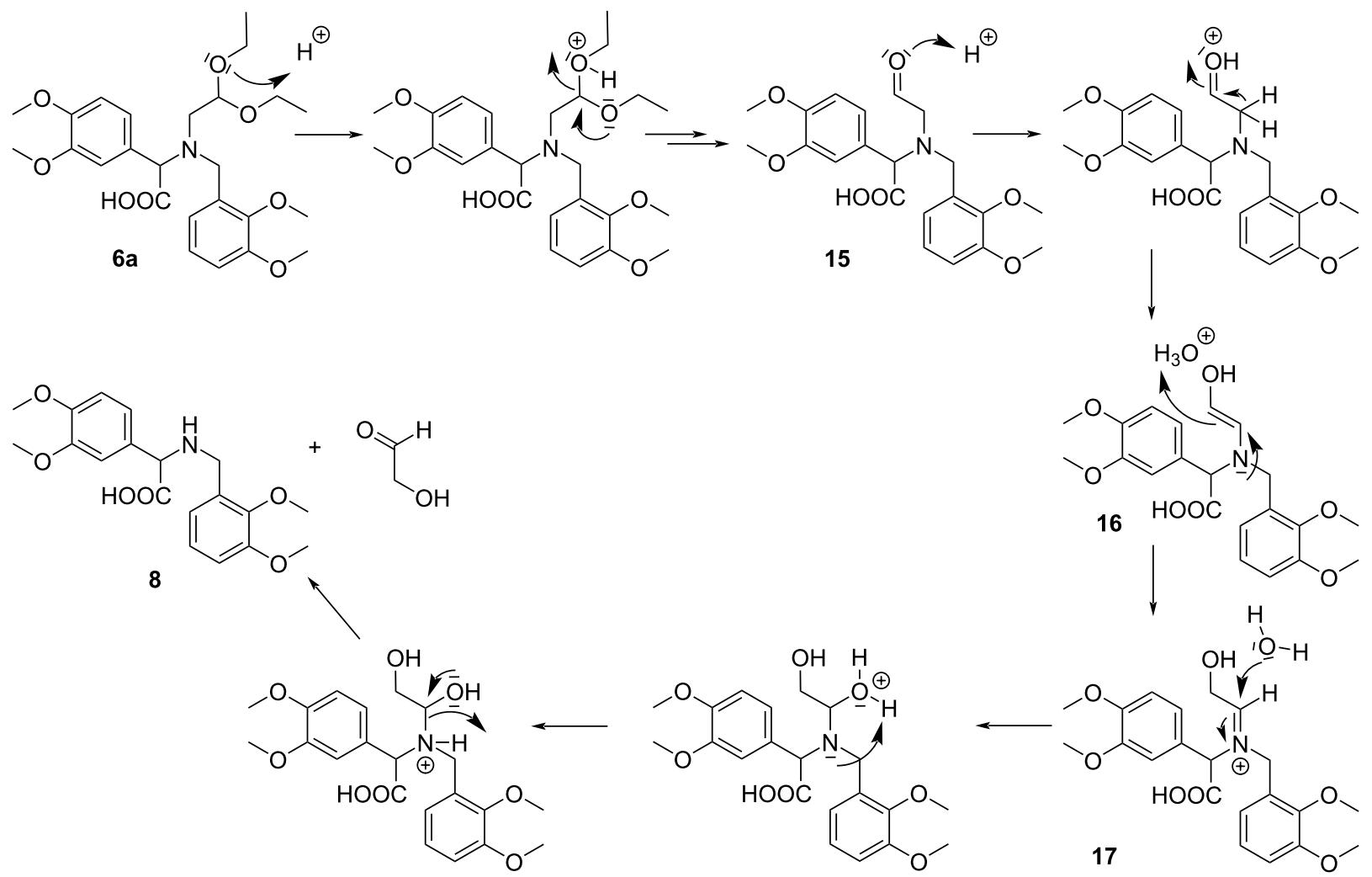


acetal function in $\mathbf{6 a}$ to afford aldehyde 15; the second step is the enolization of the aldehyde $\mathbf{1 5}$ to form the tautomeric compound 16; the next step involves the formation of the iminium ion 17, which is then hydrolyzed to compound 8 and hydroxyacetaldehyde in the last step.

Thus, the unexpected reactivity of $\mathbf{6 a}$ with diluted $\mathrm{HCl}$ may be explained by the electron-withdrawing effect exerted by the adjacent $\mathrm{COOH}$ group which facilitates hydrolysis of the iminium ion 17

\section{Conlusion}

In conclusion, a straightforward and efficient method for the synthesis of new tetrahydroisoquinoline derivatives, 7,12dihydro-6,12-methanodibenzo[c,f]azocine-5-carboxylic acids 7a-f has been developed. It is based on the Petasis reaction with the use of aminoacetaldehyde acetals bearing substituted benzyl groups as the amine components followed by Pomeranz-Fritsch double cyclization reaction. The presence of the carboxyl group in 7a-f allows synthesis of new derivatives of these unexplored tetracyclic tetrahydroisoquinolines for biochemical studies. The unusual interesting behavior of Petasis reaction product $\mathbf{6 a}$ in diluted $\mathrm{HCl}$ solution leading to phenylglycine derivative $\mathbf{8}$ has been detected and the mechanism explaining this reactivity has been proposed.

\section{Supporting Information}

\author{
Supporting Information File 1 \\ Experimental. \\ [https://www.beilstein-journals.org/bjoc/content/ \\ supplementary/1860-5397-17-168-S1.pdf]

\section{Supporting Information File 2} \\ Copies of ${ }^{1} \mathrm{H}$ NMR and ${ }^{13} \mathrm{C}$ NMR spectra. \\ [https://www.beilstein-journals.org/bjoc/content/ \\ supplementary/1860-5397-17-168-S2.pdf]
}

\section{Acknowledgements}

Katarzyna Nowakowska is gratefully acknowledged for preliminary experiments.

\section{Funding}

This work was supported by the research grant from the Polish National Science Centre (NCN) No. 2011/01/D/ST5/06627.

\section{ORCID ${ }^{\circledR}$ iDs}

Agnieszka Grajewska - https://orcid.org/0000-0001-8645-4043 Maria Chrzanowska - https://orcid.org/0000-0002-8292-4762 Wiktoria Adamska - https://orcid.org/0000-0002-4024-8479

\section{References}

1. Scott, J. D.; Williams, R. M. Chem. Rev. 2002, 102, 1669-1730. doi:10.1021/cr010212u

2. Bentley, K. W. Nat. Prod. Rep. 2005, 22, 249-268. doi:10.1039/b316108k

3. Bentley, K. W. The Isoquinoline Alkaloids; Harwood Academic Publishers: Amsterdam, 1998.

4. Chrzanowska, M.; Rozwadowska, M. D. Chem. Rev. 2004, 104, 3341-3370. doi:10.1021/cr030692k

5. Chrzanowska, M.; Grajewska, A.; Rozwadowska, M. D. Chem. Rev. 2016, 116, 12369-12465. doi:10.1021/acs.chemrev.6b00315

6. Weber, E.; Keana, J.; Barmettler, P. PCP Receptor ligands and the use thereof. International Patent Application WO90/12575A1, Nov 1, 1990.

7. Childers, W. E., Jr..; Abou-Gharbia, M. A. 10,11-Dihydro-5-alkyl-12-substituted-10,5-(iminomethano)-5H-dibenzo $[A D]$ cycloheptenes as Neuroprotectant Agents. U.S. Patent US4,940,789, July 10, 1990.

8. Hanessian, S.; Mauduit, M. Angew. Chem., Int. Ed. 2001, 40, 3810-3813.

doi:10.1002/1521-3773(20011015)40:20<3810::aid-anie3810>3.0.co;28

9. Hanessian, S.; Parthasarathy, S.; Mauduit, M.; Payza, K. J. Med. Chem. 2003, 46, 34-48. doi:10.1021/jm020164l

10. Hanessian, S.; Mauduit, M.; Demont, E.; Talbot, C. Tetrahedron 2002, 58, 1485-1490. doi:10.1016/s0040-4020(02)00012-1

11. Nomoto, T.; Nasui, N.; Takayama, H. J. Chem. Soc., Chem. Commun. 1984, 1646-1647. doi:10.1039/c39840001646

12. Suzuki, T.; Takamoto, M.; Okamoto, T.; Takayama, H. Chem. Pharm. Bull. 1986, 34, 1888-1900. doi:10.1248/cpb.34.1888

13. Coşkun, N.; Buyukuysal, L. Heterocycles 1998, 48, 53-59. doi:10.3987/com-97-7986

14. Bobbitt, J. M.; Shibuya, S. J. Org. Chem. 1970, 35, 1181-1183. doi:10.1021/jo00829a074

15. Yamada, K.; Takeda, M.; Itoh, N.; Ohtsuka, H.; Tsunashima, A.; Iwakuma, T. Chem. Pharm. Bull. 1982, 30, 3197-3201. doi:10.1248/cpb.30.3197

16. Mottinelli, M.; Leese, M. P.; Potter, B. V. L. Beilstein J. Org. Chem. 2017, 13, 1871-1878. doi:10.3762/bjoc.13.182

17. Hara, H.; Hoshino, O.; Umezawa, B. Chem. Pharm. Bull. 1985, 33, 2705-2711. doi:10.1248/cpb.33.2705

18. Buev, E. M.; Stepanov, M. A.; Moshkin, V. S.; Sosnovskikh, V. Y. Org. Lett. 2020, 22, 631-635. doi:10.1021/acs.orglett.9b04401

19. Chrzanowska, M.; Grajewska, A.; Meissner, Z.; Rozwadowska, M. D.; Wiatrowska, I. Tetrahedron 2012, 68, 3092-3097. doi:10.1016/j.tet.2012.02.005

20. Chrzanowska, M.; Grajewska, A.; Rozwadowska, M. D. Heterocycles 2012, 86, 1119-1127. doi:10.3987/com-12-s(n)59

21. Bułyszko, I.; Chrzanowska, M.; Grajewska, A.; Rozwadowska, M. D. Eur. J. Org. Chem. 2015, 383-388. doi:10.1002/ejoc.201403218 


\section{License and Terms}

This is an Open Access article under the terms of the Creative Commons Attribution License (https://creativecommons.org/licenses/by/4.0). Please note that the reuse, redistribution and reproduction in particular requires that the author(s) and source are credited and that individual graphics may be subject to special legal provisions.

The license is subject to the Beilstein Journal of Organic Chemistry terms and conditions:

(https://www.beilstein-journals.org/bjoc/terms)

The definitive version of this article is the electronic one which can be found at:

$\underline{\text { https://doi.org/10.3762/bjoc.17.168 }}$ 